\title{
10. DEEP-WATER PLIOCENE-PLEISTOCENE FORAMINIFERS AND OCEANOGRAPHY (LESSER ANTILLES FOREARC), LEG 110, SITE 672 ${ }^{1}$
}

\author{
Murlene W. Clark ${ }^{2}$
}

\begin{abstract}
Site 672 is located on the Atlantic abyssal plain to the east of the Lesser Antilles forearc region. It serves as a stratigraphic reference section for sediments entering the Barbados accretionary prism. A relatively complete Pliocene through lower Pleistocene section was recovered from Site 672 that contains a moderately well-preserved population of benthic foraminifers. Q-mode factor analysis of the benthic population data identified three Pliocene-Pleistocene assemblages that inhabited this site. The Factor 1 fauna, characterized by Nuttallides umboniferus, is commonly associated with the presence of Antarctic Bottom Water (AABW). The Factor 2 assemblage is characterized by Globocassidulina subglobosa, Epistominella exigua, and a combined category of unilocular species. The Factor 3 assemblage is characterized by Epistominella exigua, and Planulina wuellerstorfi. The Factor 2 and 3 faunas are associated with bottom water significantly warmer than that preferred by the Factor 1 assemblage.

The distribution of these assemblages has been used to distinguish three climatic intervals in the abyssal environment during the Pliocene-Pleistocene. An early Pliocene warm interval occurred from the Ceratolithus rugosus Subzone to the middle of the Discoaster tamalis Subzone. The upper Pliocene is characterized by oscillations between the Factor 1 and Factor 2 assemblages, which suggests climatic deterioration and increased pulses of AABW flow. The persistence of an essentially modern (Factor 1) fauna throughout the early Pleistocene suggests full glacial development at both poles and a substantial volume of AABW production.
\end{abstract}

\section{INTRODUCTION}

Benthic foraminifer populations in the Atlantic Ocean have been studied extensively to determine the distribution and migration patterns of Neogene deep-water masses. Correlations between principal assemblage components and specific Neogene water masses have been proposed for the Atlantic by Streeter (1973), Schnitker (1974, 1980), Weston and Murray (1984), and Lohmann (1978). Streeter (1973) used data compiled in Quaternary taxonomic studies by Phleger et al. (1953) to determine the relationship between benthic populations and specific deep-water masses. Schnitker $(1974,1980)$ examined abyssal assemblages in the western North Atlantic and established faunal associations for Antarctic Bottom Water (AABW), Arctic Bottom Water (ABW), and upper and lower North Atlantic Deep Water (NADW). Similar relationships between modern assemblages and overlying water masses in the eastern North Atlantic were determined by Weston and Murray (1984). South Atlantic studies have yielded important information that correlates specific modern assemblages with water masses such as AABW and NADW (Lohmann, 1978).

Patterns of deep-water mass distribution can be monitored by changes in benthic assemblage even though the physical water mass characteristics preferred by individual species are not well understood. The modern deep-water environment is characterized by a fauna of cosmopolitan distribution. Associations between water mass and assemblage are based on shifts in species dominance within an otherwise stable population. The complex interaction between Neogene water-mass distribution and changes in global climate can be interpreted through relatively subtle changes in the abyssal fauna. During the Neogene, deep ocean circulation was strongly influenced by progressive cli-

\footnotetext{
${ }^{1}$ Moore, J. C., Mascle, A., et al., 1990. Proc. ODP, Sci. Results, 110: College Station, TX Ocean Drilling Program.

2 Department of Geology and Geography, University of South Alabama, Mobile, AL 36688 .
}

matic deterioration, which eventually resulted in full glacial development at both poles. Because water-mass history is related to the glacial history of both hemispheres, important paleoclimatic information can be gathered from abyssal population dynamics. Site 672 provides a window into the Pliocene-Pleistocene abyssal environment through which changes in the deep Atlantic water-mass structure can be monitored from a low-latitude vantage point. Located $6 \mathrm{~km}$ east of the deformation front $\left(15^{\circ} 32.40^{\prime} \mathrm{N}, 58^{\circ} 38.46^{\prime} \mathrm{W}\right)$, Site 672 was drilled as a biostratigraphic reference section for sediments entering the Barbados accretionary prism (Fig. 1). Because this site has not yet been affected by subduction processes active in the Lesser Antilles forearc region, a relatively undisturbed Pliocene-Pleistocene section is available for study. Water depth at this site was recorded at $4973 \mathrm{~m}$; lower abyssal paleodepths are therefore estimated for the late Neogene section on which this study is focused.

Sediments recovered at Site 672 range in age from Eocene to early Pleistocene (Shipboard Scientific Party, 1988). The Paleogene sequence is somewhat recrystallized and punctuated by unfossiliferous intervals of clastic sediment derived from the South American Continent (Dolan et al., this volume). The Miocene section is composed of mudstones and claystones that are very low in carbonate content $(0-15 \%)$. Intense episodes of dissolution produced by upward excursions of the Miocene CCD are responsible for the low carbonate values and subsequently poor biostratigraphic resolution in this part of the section.

The Pliocene-Pleistocene sediments are hemipelagic in character with an average carbonate content of between 20 and $40 \%$. This interval ranges in age from the early Pliocene Ceratolithus rugosus Subzone (CN10c) of Okada and Bukry (1980) through the early Pleistocene Pseudoemiliania lacunosa Zone of Gartner (1977). The early Pleistocene Helicosphaera sellii Zone of Gartner (1977) was the only biostratigraphic interval not represented in the sequence.

Preservation of the Pliocene-Pleistocene assemblage is moderate to good; however, discrete intervals within this section have been strongly affected by dissolution. Dissolved sediments occur in Samples 110-672A-1H-1, 71-73 cm, and 110-672A-2H-1, 


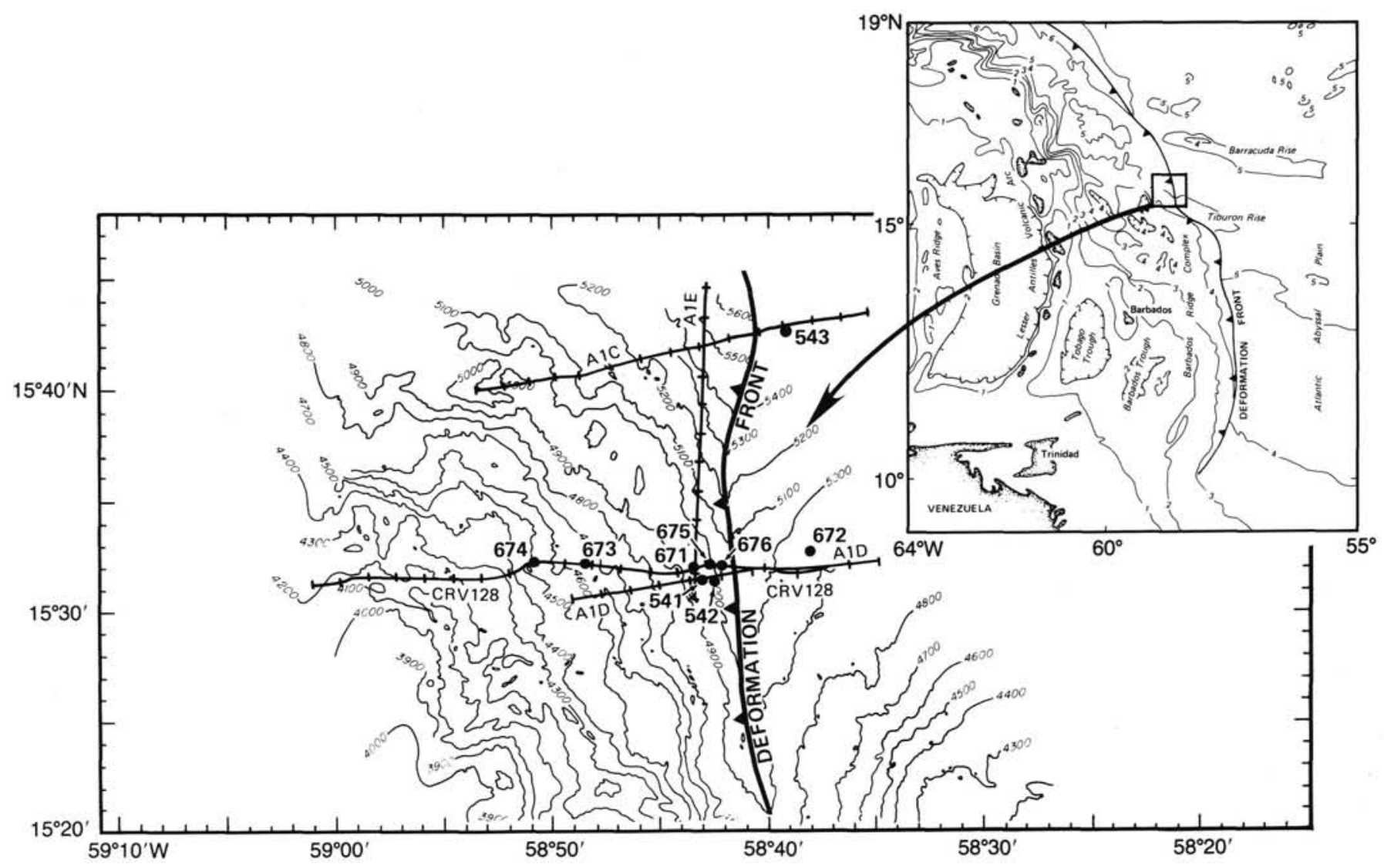

Figure 1. Location of ODP Site 672. Bathymetry in meters.

$81-83 \mathrm{~cm}$, of early Pleistocene age, Samples 110-672A-5H-CC, $-6 \mathrm{H}-\mathrm{CC}$, and $-7 \mathrm{H}-5,80-82 \mathrm{~cm}$, of late Pliocene age, and Sample $110-672 \mathrm{~A}-12 \mathrm{H}-6,82-84 \mathrm{~cm}$, of early Pliocene age. Core 110 $672 \mathrm{~A}-12 \mathrm{H}$ samples are, on the whole, poorly preserved.

\section{METHODS}

Seventy-five samples were washed with a $63-\mu \mathrm{m}$ sieve and air dried. Statistical splits were then picked from the size fraction $>125 \mu \mathrm{m}$. Whenever possible, 100 benthic specimens were picked from each of the washed residues; usually between 100 and 200 specimens were obtained per sample. A factor analysis was performed on the benthic population data by means of the program CABFAC (Klovan and Imbrie, 1971). Results of this analysis are displayed in Table 1 . Samples with less than 100 specimens or samples that had experienced high levels of dissolution were

Table 1. Pliocene-Pleistocene assemblages at Site 672 identified by varimax factors.

\begin{tabular}{|c|c|c|c|}
\hline Factor & $\begin{array}{l}\text { Percent } \\
\text { variance }\end{array}$ & Principal components & $\begin{array}{l}\text { Varimax factor } \\
\text { score }\end{array}$ \\
\hline \multirow[t]{2}{*}{ Factor 1} & \multirow[t]{2}{*}{78.73} & Nuttallides umboniferus & 0.983 \\
\hline & & Epistominella exigua & -0.111 \\
\hline \multirow[t]{7}{*}{ Factor 2} & \multirow[t]{7}{*}{8.63} & Globocassidulina subglobosa & 0.832 \\
\hline & & Epistominella exigua & 0.369 \\
\hline & & Unilocular species & 0.221 \\
\hline & & Pullenia quinqueloba & 0.176 \\
\hline & & Pullenia lucernula & 0.171 \\
\hline & & Nuttalides umboniferous & 0.132 \\
\hline & & Eggerella bradyi & 0.113 \\
\hline \multirow[t]{4}{*}{ Factor 3} & \multirow[t]{4}{*}{2.74} & Epistominella exigua & 0.679 \\
\hline & & Planulina wuellerstorfi & 0.623 \\
\hline & & Globocassidulina subglobosa & -0.291 \\
\hline & & Eggerella bradyi & 0.101 \\
\hline
\end{tabular}

omitted from the study. These intervals represent a potential source of bias from small sample size or from the selective removal of dissolutionsusceptible species. Samples were identified as highly dissolved if significant fragmentation of benthic specimens was observed. Moderate levels of dissolution will result in fragmentation of less-resistant planktonic species whereas extreme levels of dissolution will result in fragmentation and removal of benthic specimens. If significant numbers of benthic species are removed from the assemblage, quantitative description of the fauna will be compromised.

The taxonomic notes for this study are found in the Appendix and a partial range chart is included in Table 2. Unilocular species that belong to Oolina, Fissurina, Parafissurina, and Lagena are tabulated as a single entry on the range chart and are entered as such in the factor analysis of the data.

\section{RESULTS}

Populations of benthic foraminifers studied at Site 672 are remarkably consistent with respect to overall species composition. Species such as Globocassidulina subglobosa, Nuttallides umboniferus, Epistominella exigua, Eggerella bradyi, Planulina wuellerstorfi, Pullenia osloensis, and Oridorsalis umbonatus are dominant faunal constituents throughout the PliocenePleistocene section. Shifts in species abundance among these taxa, identified through factor analysis techniques, are used to interpret changes in the deep Neogene water-mass structure.

\section{Factor Analysis}

Pliocene-Pleistocene samples from ODP Site 672 were resolved through a varimax, Q-mode factor analysis. Three factors were identified with eigenvalues of 2.00 or greater that together explain $90 \%$ of the variance in the data set (Table 1). Factor 1 strongly identifies Nuttallides umboniferus as the principal component. This species has consistently been correlated with 
AABW in previous Atlantic studies (Streeter, 1973, Schnitker, 1974, 1980, Bremer and Lohmann, 1982, Lohmann 1978, Weston and Murray, 1984). At a depth of $4973 \mathrm{~m}$, Site 672 is presently within the range of influence of AABW (Lynn and Reid, 1968); peaks in the abundance of Nuttallides umboniferus can reasonably be correlated with the presence of this water mass in the Holocene.

The Factor 2 assemblage is primarily characterized by Globocassidulina subglobosa. Epistominella exigua and the unilocular species are identified as important secondary components. Weston and Murray (1984) observed a Globocassidulina subglobosa fauna in the eastern North Atlantic that they associated with deep water from the Mediterranean Sea. Corliss (1979) observed a G. subglobosa-dominated assemblage from the southern Indian Ocean that he correlated with the upper, warmer portion of AABW formed by the mixing of AABW with Indian Bottom Water. The Factor 2 fauna at Site 672 clearly is associated with a different (probably warmer) water mass than the Factor 1 assemblage. The fact that unilocular species were entered in the factor analysis in combined form may have artifically enhanced the factor score of this group.

Factor 3 is identified by the co-dominant species Epistominella exigua and Planulina wuellerstorfi. Streeter (1973) correlated these taxa with North Atlantic Deep Water (NADW) of between 2 and $3^{\circ} \mathrm{C}$. Schnitker (1980) also associated Epistominella exigua and Planulina wuellerstorfi with NADW.

\section{Paleoceanographic Interpretation}

\section{Early Pliocene}

The lowermost Pliocene section at Site 672 is characterized by Factor 1 (Nuttallides umboniferus) fauna (Fig. 2). Nuttallides umboniferus was correlated with conditions of carbonate undersaturation by Bremer and Lohmann (1982) and is characteristic of corrosive water masses such as AABW. Strong dissolution of Miocene sediments in most areas of the Atlantic suggests extensive elevation of the Miocene CCD (Berger and von Rad, 1972, van Andel, 1975). At Site 672, Miocene sediments are intensely dissolved, as are those of the earliest Pliocene. The CCD was probably still elevated during the earliest Pliocene, instigated by the phenomenon that produced upward excursions of the Miocene CCD. Heightened levels of carbonate undersaturation may have favored the Factor 1 assemblage; therefore, no positive relationship is inferred between bottom water from an Antarctic source and the Factor 1 assemblage for the early Pliocene.

Dominance patterns rapidly changed in the lower portion of the Ceratolithus rugosusy Subzone (CN10c). A shift is observed from the Factor 1 assemblage to the warmer Factor 2 and 3 faunas (Fig. 2). The early Pliocene fauna alternates between a Globocassidulina subglobosa assemblage and one identified by $\mathrm{Pla}$ nulina wuellerstorfi and Epistominella exigua. Both of these assemblages have been associated with water masses in the Atlantic significantly warmer than AABW. These warm faunas appear to have dominated the deep, low-latitude regions of the western Atlantic from the early Pliocene Ceratolithus rugosus Subzone until the middle of the late Pliocene Discoaster tamalis Subzone, when Site 672 samples again shift toward the cold-water Factor 1 assemblage (Fig. 2).

The idea of a warm early Pliocene is supported by the isotopic work of Oberhansli and Hemleben (1984) from samples taken on Leg 78 in the Lesser Antilles forearc region. They found that a positive isotopic shift occurred in planktonic foraminifer tests at $4.5 \mathrm{Ma}$. This indicates that the surface waters of the early Pliocene were warmer than those of the Miocene. These isotopic data further suggest that the warming trend continued until 2.7 to $2.9 \mathrm{Ma}$ when climatic deterioration produced a de- cline in surface water temperatures and the eventual onset of northern hemispheric glaciation. Both of these isotopic changes can be correlated with benthic faunal shifts observed in the present study. Site 672 faunal changes, which occur in the early Pliocene $C$. rugosus Zone (CN10b) and in the Discoaster tamalis Subzone, are roughly synchronous with the 4.5- and 2.7-Ma isotopic shifts of Oberhansli and Hemleben (1984).

Patterns of early Pliocene warming in the South Atlantic were also deduced from isotopic examination of abyssal foraminifers from the Angola Basin (Weissert et al., 1984) and by studies of siliceous faunas from the Southern Ocean (Ciesielski and Weaver, 1974). Oberlansli and Hemleben (1984) recognized three climatic divisions of the Pliocene-Pleistocene. The early Pliocene (5.2-3.3 Ma) was an isotopically warm interval with diminished antarctic glaciers. Between 3.3 and 2.5 Ma the Pliocene climate deteriorated and ice volumes began to increase in both hemispheres. An additional shift in isotopic values signaled increased climatic cooling between 2.5 and 1.1 Ma. Although these changes are analogous to those observed in Site 672 samples, shifts in temperature were indicated slightly earlier in the Southern Hemisphere than in the Caribbean.

\section{Late Pliocene}

The late Pliocene fauna appears to oscillate between the Factor 1 and Factor 2 assemblage (Fig. 2). This suggests that AABW and a substantially warmer bottom water alternately influenced the Lesser Antilles forearc region. Pulses of AABW, caused by changes in global ice volume, may have produced the observed shifts in the deep-water population. The population may have periodically adjusted to cycles of increased vs. attenuated AABW flow. In addition to climatic influences, the faunal shifts may have been caused by changes in Caribbean circulation patterns effected through the closing of the Panamanian Seaway. The connection with equatorial Pacific waters is thought to have ended around $3 \mathrm{Ma}$ (Keigwin, 1979). The gradual elimination of Pacific components from the Atlantic Basin at that time may have increased the influence of AABW on the deep-water population and therefore produced the observed patterns of faunal change.

\section{Early Pleistocene}

Early Pleistocene samples from Site 672 are dominated by the Factor 1 (Nuttallides umboniferus) assemblage (Fig. 2) indicative of AABW. Northern and southern hemispheric glaciation was well established during the early Pleistocene and AABW volume was probably sufficient at that time to significantly influence low-latitude abyssal assemblages. No evidence was observed in Site 672 samples for glacial vs. interglacial changes in the deep abyssal environment, although previous investigations of Caribbean surface waters (Oberhansli and Hemleben, 1984) and deep Atlantic populations (Streeter, 1973, Schnitker, 1974, 1980 ) indicated distinct Pleistocene glacial vs. interglacial faunal associations. Site 672 samples indicate that this region of the Atlantic exhibited a stable fauna of essentially modern character throughout the early Pleistocene.

\section{CONCLUSION}

Low-latitude abyssal populations from the western Atlantic remained relatively stable throughout the Pliocene-Pleistocene. Extinction and origination events were rare, and changes in the population were restricted to shifts in patterns of species dominance. Dominance shifted between seven faunal constituents: Nuttallides umboniferus, Globocassidulina subglobosa, Epistominella exigua, Oridorsalis umbonatus, Planulina wuellerstorfi, Eggerella bradyi, and Pullenia osloensis, in response to changes in the abyssal environment. 
Table 2. Pliocene-Pleistocene distribution of benthic foraminifers from Hole 672A.

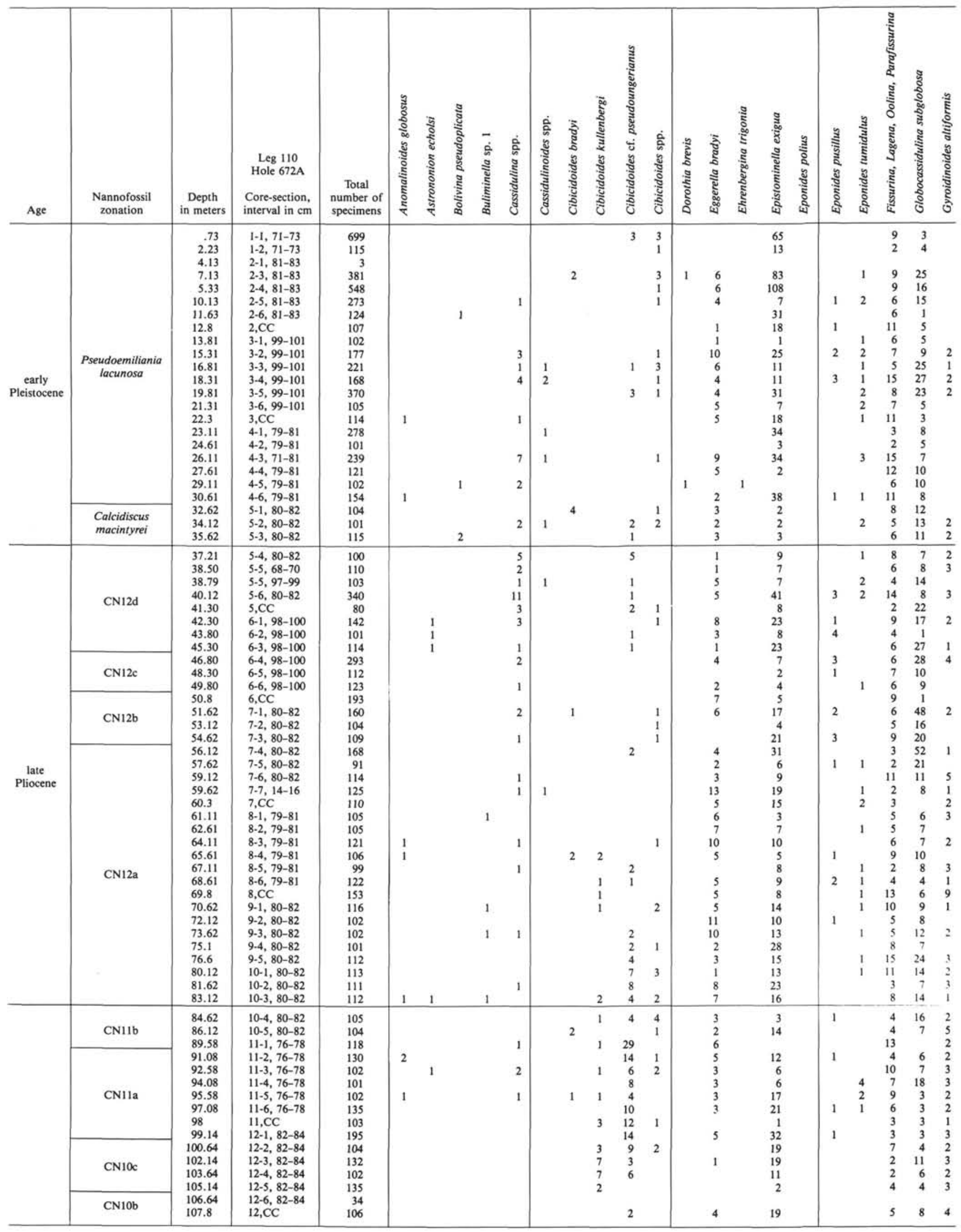




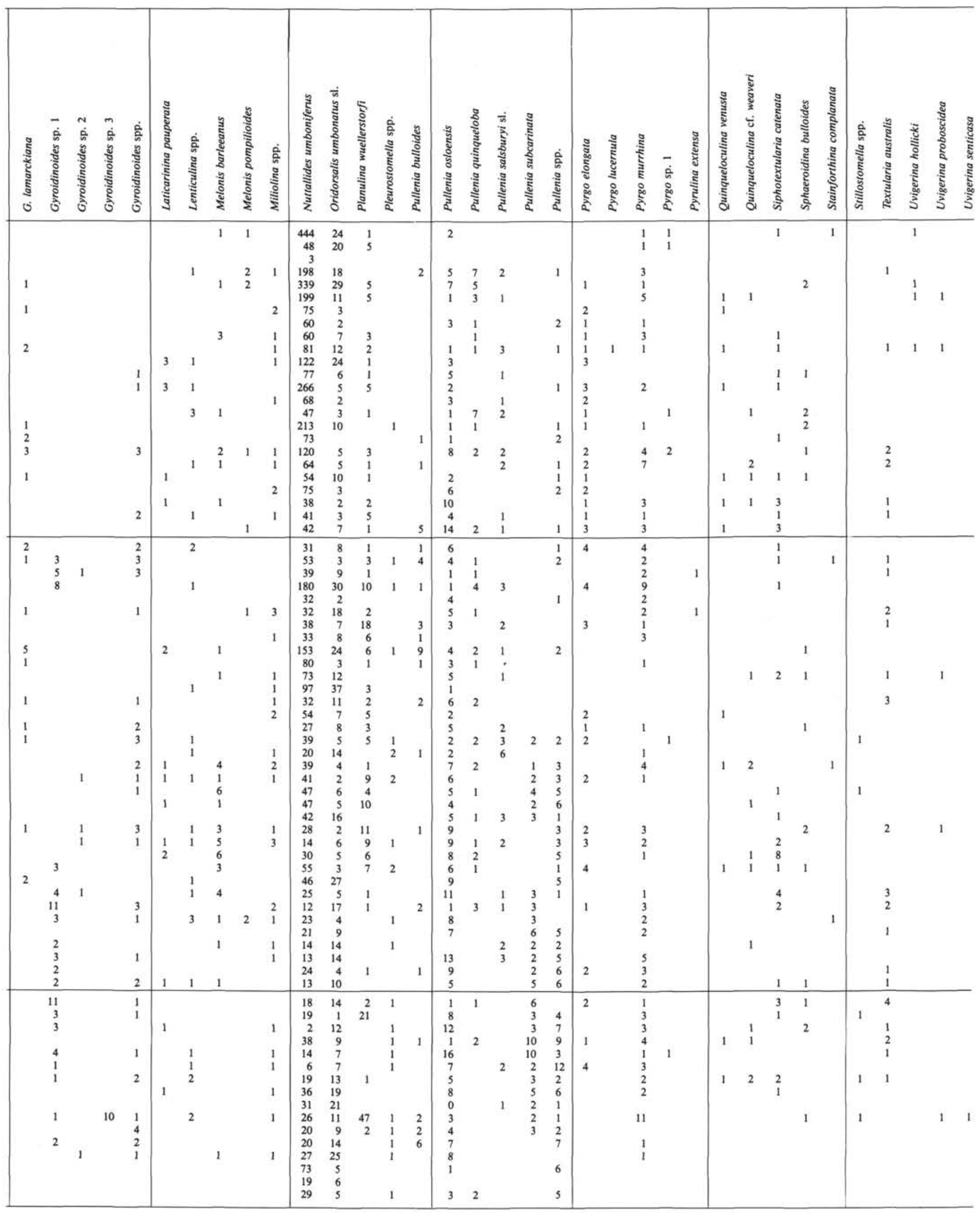



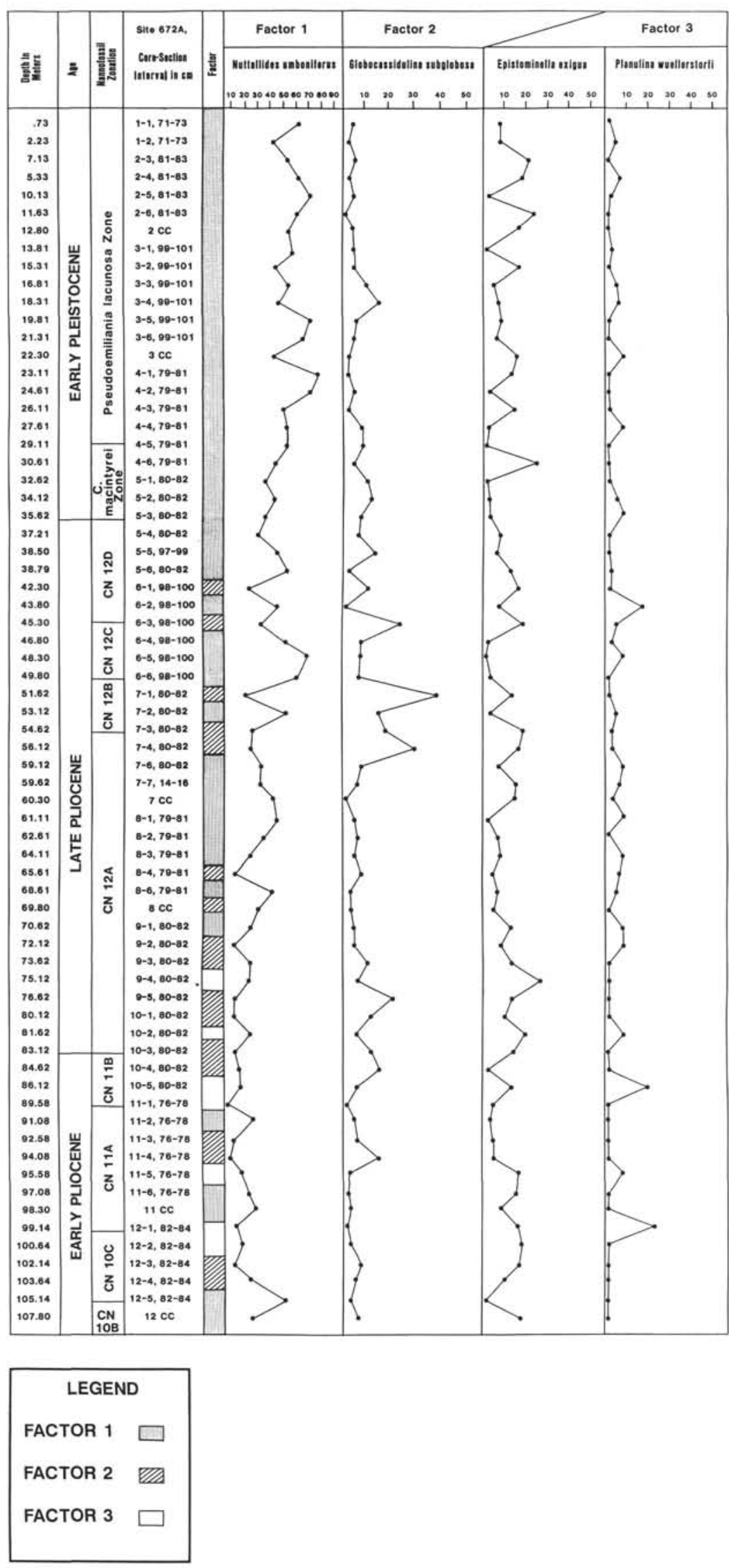

Figure 2. Correlation between Site 672 samples, Q-mode varimax factors, and distribution of principal factor components. 
The earliest Pliocene section is strongly associated with Nuttallides umbon iferus, probably in response to an elevation of the CCD initiated during the Miocene. Faunas indicative of warmer bottom water dominate from the early Pliocene Ceratolithus rugosus Subzone $(\mathrm{CN} 10 \mathrm{c})$ through the beginning of the Discoaster tamalis Subzone (CN12a) of early late Pliocene age.

The late Pliocene was a time of change in the abyssal environment as evidenced by shifts between the warm-water Factor 2 fauna characteristic of the early Pliocene and the Factor 1 assemblage that is associated with AABW production. Alternations between the two faunas lasted until the latest Pliocene $D$. brouweri $(\mathrm{CN} 12 \mathrm{~d})$ Zone. From this point through the early Pleistocene the abyssal fauna was essentially modern in character. Domination by the Factor 1 fauna in the early Pleistocene suggests isolation from Pacific waters and a substantial volume of AABW flow.

\section{ACKNOWLEDGMENTS}

I express my appreciation to Mobil Oil Corporation for drafting support and to Jack Koch, Jr. for preparation of SEM illustrations. I also thank R. E. Hennington and Elaine Goldstein for valuable taxonomic discussions and R. K. Clark and Dr. Wayne Isphording for assistance in the factor analysis phase of this project.

\section{REFERENCES}

Berger, W. H., and von Rad, U., 1972. Cretaceous and Cenozoic sediments from the Atlantic Ocean. In Hays, D. E., Pimm, A. C., et al., Init. Repts. DSDP, 14: Washington (U.S. Govt. Printing Office), 787-954.

Bremer, M. L., and Lohmann, G. P., 1982. Evidence for primary control of the distribution of certain Atlantic Ocean benthonic foraminifera by degree of carbonate saturation. Deep-Sea Res., 29:987998.

Ciesielski, P. F., and Weaver, F. M., 1974. Early Pliocene temperature changes in the Antarctic Seas. Geology, 2:511-515.

Corliss, B. H., 1979. Taxonomy of Recent deep sea benthonic foraminiferal from the southeast Indian Ocean. Micropaleontology, 25:119.

Gartner, S., Jr., 1977. Calcareous nannofossil biostratigraphy and revised zonation of the Pleistocene. Mar. Micropaleontol., 2:1-25.

Keigwin, L., 1979. Late Cenozoic stable isotope stratigraphy and paleoceanography of Deep Sea Drilling Project sites from the east equatorial and central North Pacific Ocean. Earth. Planet. Sci. Lett., 45: 361-382.

Klovan, J. E., and Imbrie, J., 1971. An algorithm and fortran IV program for large scale Q-mode factor analysis. J. Int. Assoc. Math. Geol., 3:61-78.

Lohmann, G. P., 1978. Abyssal benthonic foraminifera as hydrographic indicators in the western South Atlantic Ocean. J. Foraminiferal Res., $8: 6-34$.

Lynn, R. J., and Reid, J. L., 1968. Characteristics and circulation of deep and abyssal waters. Deep-Sea Res., 15:577-598.

Oberhansli, H., and Hemleben, C., 1984. Stable isotope record of the Pliocene and Pleistocene planktonic foraminifers from Leg 78A, Sites 541 and 543, on the Barbados Ridge complex. In Biju-Duval, B., and Moore, J. C., et. al., Init. Repts. DSDP, 78A: Washington (U.S. Govt. Printing Office), 499-508.

Okada, H., and Bukry, D., 1980. Supplementary modification and introduction of code numbers to the "Low-latitude coccolith biostratigraphic zonation" (Bukry, 1973; 1975). Mar. Micropaleontol., 5: 321-325.

Phleger, F. B., Parker, F. L., and Peirson, J. F., 1953. North Atlantic Foraminifera. Sediment Cores from North Atlantic Ocean. Rep. Swed. Exp., 7:1-22.

Schnitker, D., 1974. West Atlantic abyssal circulation during the past 120,000 years. Nature, 248:385-387.

Schnitker, D., 1980. Quaternary deep sea benthic foraminifers and bottom water masses. Annu. Rev. Earth Planet. Sci., 8:343-370.

Shipboard Scientific Party, 1988. Site 672. In Mascle, A., Moore, J. C., et al., Proc. ODP Init. Repts., 110: College Station, TX (Ocean Drilling Program), 205-310.
Streeter, S. S., 1973. Bottom water and benthonic foraminifera in the North Atlantic: glacial-interglacial contrasts. Quat. Res., 3:131-141.

van Andel, T. H., 1975. Mesozoic/Cenozoic calcite compensation depth and the global distribution of calcareous sediments. Earth Planet. Sci. Lett., 26:187-194.

Weissert, H. J., McKenzie, J. A., Wright, R. C., Clark, M. W., Oberhansli, H., and Casey, M., 1984. Paleoclimatic record of the Pliocene at Deep Sea Drilling Project Sites 519, 521, 522, and 523 (central South Atlantic). In Hsü, J. K., and LaBrecque, J. L., et al., Init. Repts. DSDP, 73: Washington (U.S. Govt. Printing Office), 701-715.

Weston, J. F., and Murray, J. W., 1984. Benthic foraminifera as deep-sea water-mass indicators. Benthos '83; 2nd Int. Symp. Benthic Foraminifera (Pau, April 1983), 605-610.

Date of initial receipt: 26 July 1988

Date of acceptance: 8 May 1989

Ms 110B-134

\section{APPENDIX \\ Taxonomic Notes}

Anomalinoides globulosus (Chapman and Parr). Pl. 1, Fig. 1. Anomalina globulosa Chapman and Parr, 1937, Rep. Australasian Antarctic Exped., C, v. 1, p. 119, Pl. 9, Fig. 27. Astrononion echolsi Kennett, 1967, Pl. 1, Fig. 2. Contr. Cushman Found. Foram. Res., p. 134, Pl. 11, Figs. 7-8. Bolivina pseudoplicata Heron-Allen and Earland, 1930, J. R. Microsc. Soc., Ser. 3, v. 50, p. 81, PI. 3, Figs. 38-40. Bulimina sp 1. This buliminid is similar to the one illustrated by Kurihara and Kennett (1983) from Leg 90 to the Southwest Pacific. Cibicidoides bradyi (Trauth). PI. 1, Fig. 3. Truncatulina bradyi Trauth 1884, Denkschr. K. Akad. Wiss. Wien, Math. Naturw. Kl., v. 95, p. 235, Pl. 4, Figs. 7-9. Cibicidoides kullenbergi (Phleger, Parker, and Peirson). Cibicides kullenbergi Phleger, Parker, and Pierson, 1953, Rep. Swedish Deep Sea Exped.19471948 , v. 7, p. 49, Pl. 11, Figs. 7-8. This designation is reserved for distinctly biconvex specimens with well-developed keels. Cibicidoides $\mathrm{cf}$. pseudoungerianus (Cushman). Truncatulina pseudoungeriana Cushman, 1922, U.S. Geol. Surv. Prof. Pap., v. 1929E, p. 97, Pl. 20, Fig. 9. This small form is well represented at Site 672. It is less biconvex and has a weaker keel than C. pseudoungerianus. Site 672 forms characteristically have between 11 and 15 chambers. Dorothia brevis Cushman and Stainforth, 1945, Spec. Publ. Cushman Lab. Foram. Res., v. 14, p. 18, Pl. 2, Fig. 5. Eggerella bradyi (Cushman). Pl. 1, Fig. 4. Verneuilina bradyi Cushman, 1911, Bull. U.S. Nat. Mus., v. 71, pt. 2, p. 54, Figs. 87a-b. Ehrenbergina trigona Goes. Eherenbergina serrata var. trigona Goes, 1896, Bull. Harvard College Mus. Comp. Zool., v. 29, p. 49, pl. 6, Figs. 184-185. Epistominella exigua (Brady). Pulvinulina exigua Brady, 1884, Rep. Voy. Challenger, Zool., v. 9, p. 696, Pl. 103, Figs. 13a-c, 14a-c. Eponides polius Phleger and Parker, 1951, Mem. 46, Geol Soc. Am. Mem., no. 46, pt. 2, p. 21, Pl. 11, Figs. 1-2. Eponides pusillus Parr, 1950, Pl. 1, Fig. 7. B.A.N.Z. Antarctic Res. Exped., v. 5, pt. 6, p. 360, Pl. 14, Figs. 16a-c. Eponides tumidulus (Brady). Pl. 1, Fig. 6. Truncatulina tumidula, 1884, Rept. Voy. Challenger Zool. v. 9, p. 666, Pl. 95, Figs. 8a-d Globocassidulina subglobosa (Brady). Cassidulina subglobosa Brady, 1884, Rep. Voy. Challenger Zool. v. 9 p. 430, Pl. 54, Figs. 17a-c. Gyroidinoides altiformis Stewart and Stewart, 1930, Pl. 2, Fig. 8. J. Pal., v. 4, no. 1, p. 67, Pl. 9, Figs. 2a-c. Gyroidinoides lamarckianus (d'Orbigny). Rotalina lamarckiana d'Orbigny, 1839, Hist. Iles Canarie Foraminiferes, v. 2, pt. 2, p. 131, Pl. 2, Figs. 13-15. Gyroidinoides sp. 1. Pl, 1, Fig. 5. The distinctive spiral side of this form is characterized by radial sutures, three visible whorls, and chambers that gradually increase in size. Gyroidinoides sp. 2. Pl. 2, Fig. 9. This species is somewhat compressed in peripheral view. Gyroidinoides sp. 3. This small form occurs once in only one sample. The shape of the test is biconvex with curved sutures on the spiral side. Laticarinina pauperata (Parker and Jones). Pulvinelina repanda var. menardii subvar. pauperata Parker and Jones, 1865, Philos. Trans. R. Soc. London, v. 155, p. 395, Pl. 16, Figs. 50-51. Melonis barleeanus (Williamson). Pl. 2, Fig. 10. Nonionina barleeana Williamson, 1858, Recent Foraminifera of Great Britain, p. 32, Pl. 3, Figs. 68-69. Melonis pompilioides (Fichtel and Moll). Nautilus pompilioides Fichtel and Moll, 1798, Testacea Microscopia, p. 31, Pl. 2, Figs. a-c. Nuttallides umbonifera (Cushman). Pl. 2, Fig. 11. Pulvinulinella umbonifera Cushman, 1933, Contrib. Cushman Lab. Foram. Res., 
v. 9, pt. 4, Pl. 9, Figs. 9a-c. Oridorsalis umbonatus sl. (Reuss). Pl. 2, Fig. 13. Rotalina umbonata Reuss, 1851, Zeitschr. Deutsche. Geol. Ges., v. 3, p. 75, Pl. 5, Figs. 35a-c. Specimens of Oridorsalis tener (Brady) are included in this species designation. Planulina wuellerstorfi (Schwager). PI. 2, Fig. 12. Anomalina wuellerstorfi Schwager, 1866, Novara Exped. Geol. Theil., v. 2, p. 258, Pl. 7, Figs. 105-107. Pullenia bulloides (d'Orbigny). Pl. 3, Fig. 15. Nonionina bulloides d'Orbigny, 1846, Foraminiferes fossiles du Bassin Tertiaire de Vienne, p. 107, Pl. 5, Figs. 9-10. Pullenia osloensis Feyling-Hanssen. P1. 2, Fig. 14. Pullenia guingueloba (Reuss) subsp. minuta Feyling-Hanssen, 1954, Norsk Geol. Tidsskr., v. 33, no. 1-2, p. 133, pl. 2, Fig. 3. Pullenia osloensis Feyling-Hanssen, 1954 , Norsk Geol. Tidsskr., v. 33, nos. 3-4, p. 194. Pullenia guingueloba (Reuss). Nonionina guingueloba Reuss, 1857, Zeitschr. Deutsche. Geol. Ges., v. 3, p. 47, pl. 5, Fig. 31. Abyssal forms at Site 672 are more delicate and less calcified than forms from the Gulf of Mexico. Pullenia salisburyisl. Stewart and Stewart, 1930, J. Paleontol., v. 4, p. 72, Pl. 8, Figs. 2a,b. All compressed, lobate Pullenias with more than five chambers are placed in this group. Pullenia subcarinata (d'Orbigny). Pl. 3, Fig. 16. Nonionina subcarinata d'Orbigny, 1839, Voy. Amer. Merid. v. 5, p. 28, Pl. 5, Figs. 23, 24. Pyrgo elongata (d'Orbigny). Biloculina elongata d'Orbigny, 1826, Ann. Sci. Nat. Ser. 1, v. 7 , p. 298, no. 4. Pyro lucernula (Schwager). Biloculina lucernula Schwager 1866, Novara Exped. Geol. Thiel. v. 2, p. 202, Pl. 4, Fig. 14. Pyrgo murrhina (Schwager). Pl. 3, Fig. 18. Biloculina murrhina Schwager, 1866, Novara Exped. Geol. Theil., v. 2, p. 203, pl. 4, Figs. 15a-c. Pyrgo sp. 1. Pl. 3, Fig. 17. Pyrulina extensa (Cushman). Polymorphina extensa Cushman, 1923, Bull. U.S. Nat. Mus., v. 104, pt. 4, p. 156, Pl. 41, Figs. 7-8. Quingueloculina venusta Karrer, 1868, Pl. 3, Fig. 20. Sitzungsber. Kais. Akad. Wiss. Wien Math. Naturwiss. Kl., v. 58, Abt. 1, p. 147, Pl. 2, Fig. 6. Quingueloculina cf. weaveri Rau. Pl. 3, Fig. 19. Quingueloculina cf. weaveri Phleger, Parker and Peirson, 1953, Rep. Swedish Deep Sea Exped., 1947-1948, v. 7, p. 28, Pl. 5, Figs. 13-14. Siphotextularia catenata (Cushman). Pl. 3, Fig. 21. Textularia catenata Cushman, 1911, Bull. U.S. Nat. Mus., v. 71, pt. 2, p. 23, Figs. 39-40. Sphaeroidina bulloides d'Orbigny, 1826, Ann. Sci. Nat., Ser. 1, v. 7, p. 267 , model No. 65. Stainforthina complanata (Egger). Virgulina schreibersiana Czjzek var. complanata Egger, 1893, Abh. Bayer. Akad. Wiss. Math-Phys. Naturwiss. Kl., p. 292, Pl. 8, Figs. 91-92. Textularia australis Parr, 1950, B.A.N.Z. Antarctic Res. Exped. 1929-1931, Ser. B, v. 5, pt. 6, p. 275 , Pl. 4, Figs. 30a-c. Uvigerina hollicki Thalmann. Pl. 3, Fig. 22. Uvigerina peregrina Cushman var. bradyana Cushman, 1923, Bull. Nat. Mus., pt. 4, p. 168, Pl. 42, Fig. 12. Uvigerina hollicki Thalmann, 1950, Cushman Found. Foram. Res., v. 1, pts. 3-4, p. 45. Uvigerina proboscidea Schwager, 1866, Geol Theil, Bd. 2, Abt. 2, p. $250 \mathrm{Pl}$. 7, Fig. 96. Uvigerina senticosa Cushman, 1926, California Univ. Scripps Inst. Oceanogr. Bull., Tech. Ser., v. 1, p. 159, P1. 3, Fig. 14. 

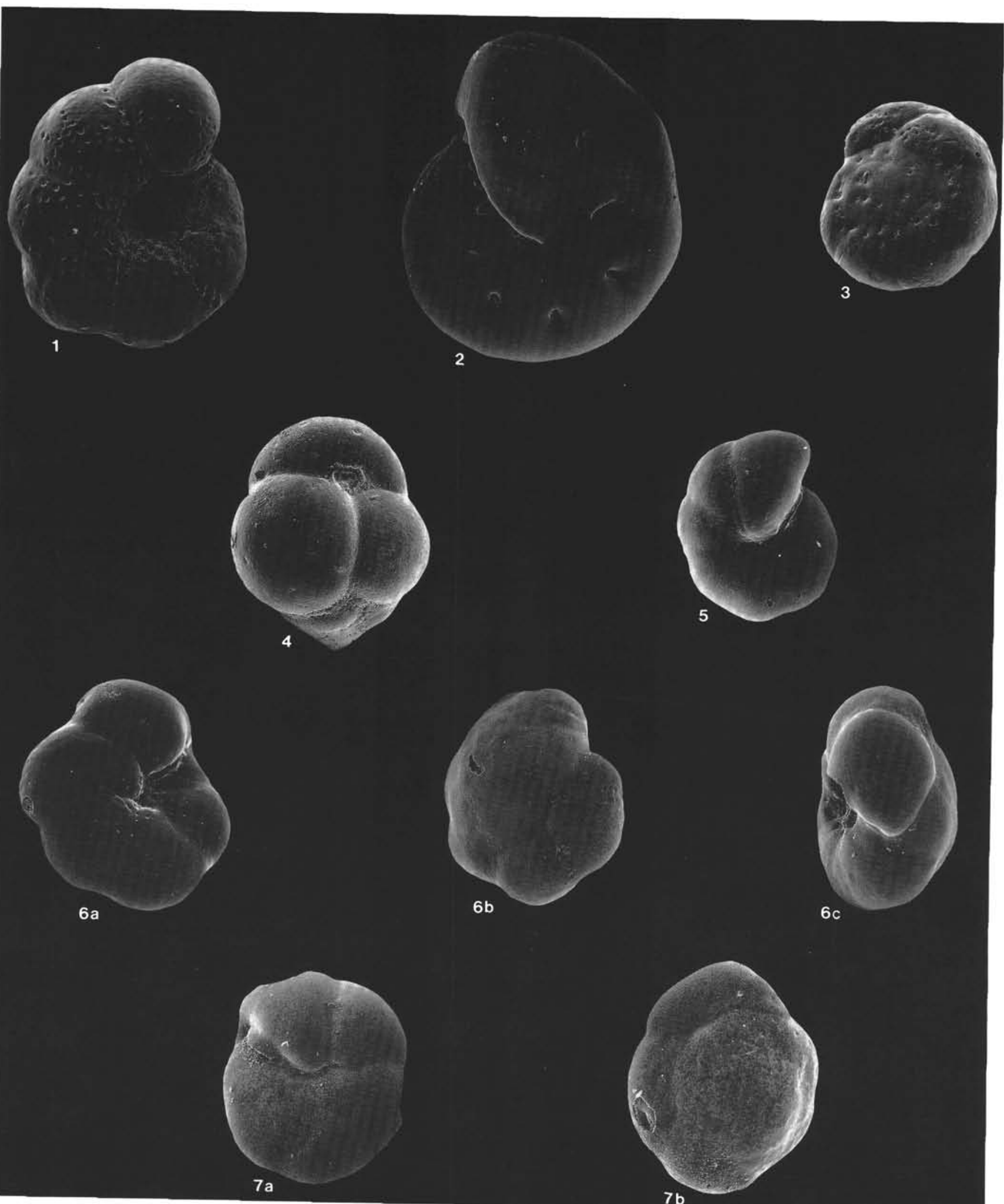

Plate 1. 1. Anomalinoides globosus, Sample 110-672A-3H-3, 99-101 cm, $\times 150$. 2. Astrononion echolsi, Sample 110-672A-6H-2, 98-100 cm, $\times 300$. 3. Cibicidoides bradyi, Sample $110-672 \mathrm{~A}-5 \mathrm{H}-1,80-82 \mathrm{~cm}, \times 150$. 4. Eggerella bradyi, Sample $110-672 \mathrm{~A}-4 \mathrm{H}-6,79-81 \mathrm{~cm}, \times 150$. 5. Gy b. Spiral view, Sample $110-672 \mathrm{~A}-5 \mathrm{H}-5,68-70 \mathrm{~cm}, \times 150$. 6. Eponides tumidulus. a. Umbilical view, Sample $110-672 \mathrm{~A}-3 \mathrm{H}-5,99-101 \mathrm{~cm}, \times 300$. 110-672A-7H-1, 80-82 cm. a. Umbilical $99-101 \mathrm{~cm}, \times 300$. c. Edge view, Sample 110-672A-3H-4, 99-101 cm, $\times 300$. 7. Eponides pusillus, Sample 


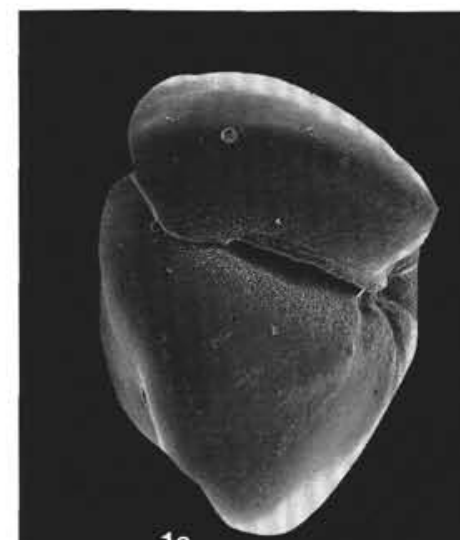

$1 \mathrm{a}$

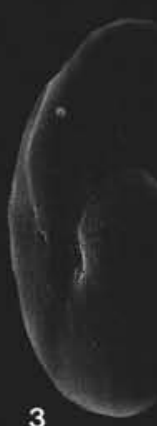

1b
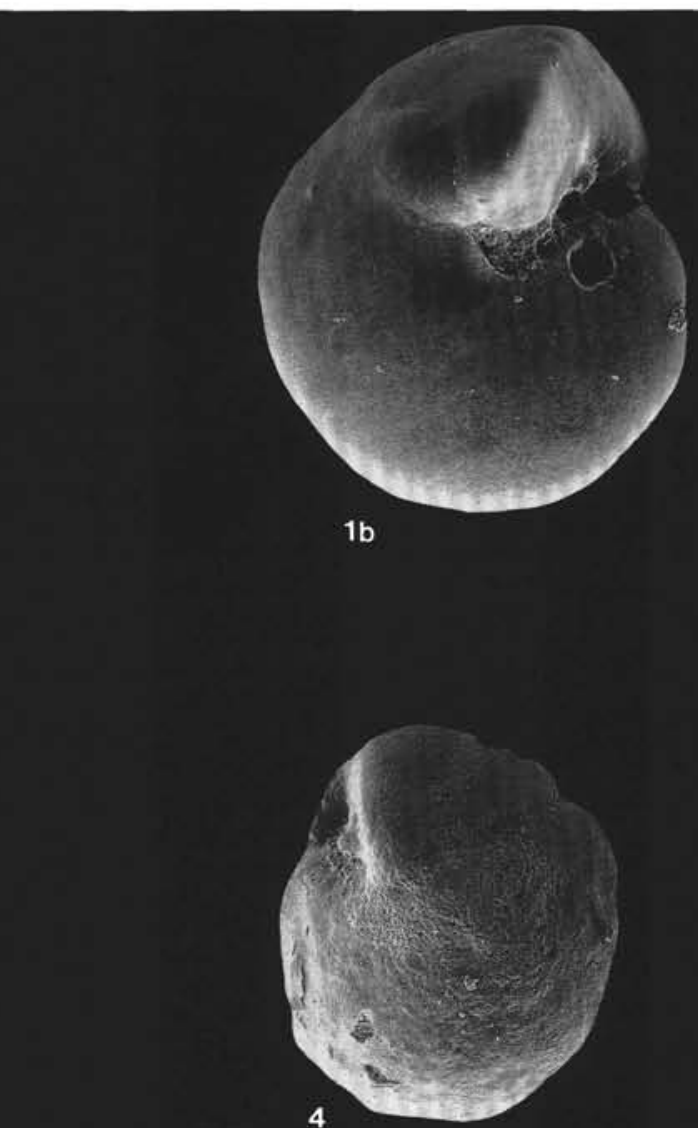

4
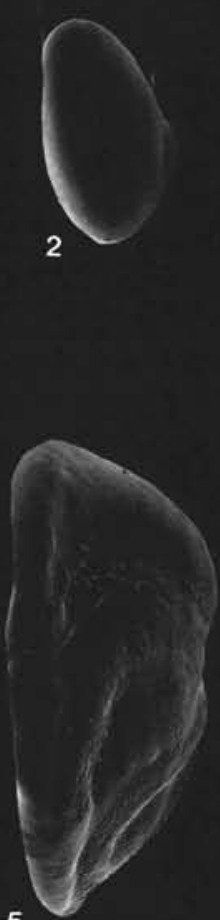

5

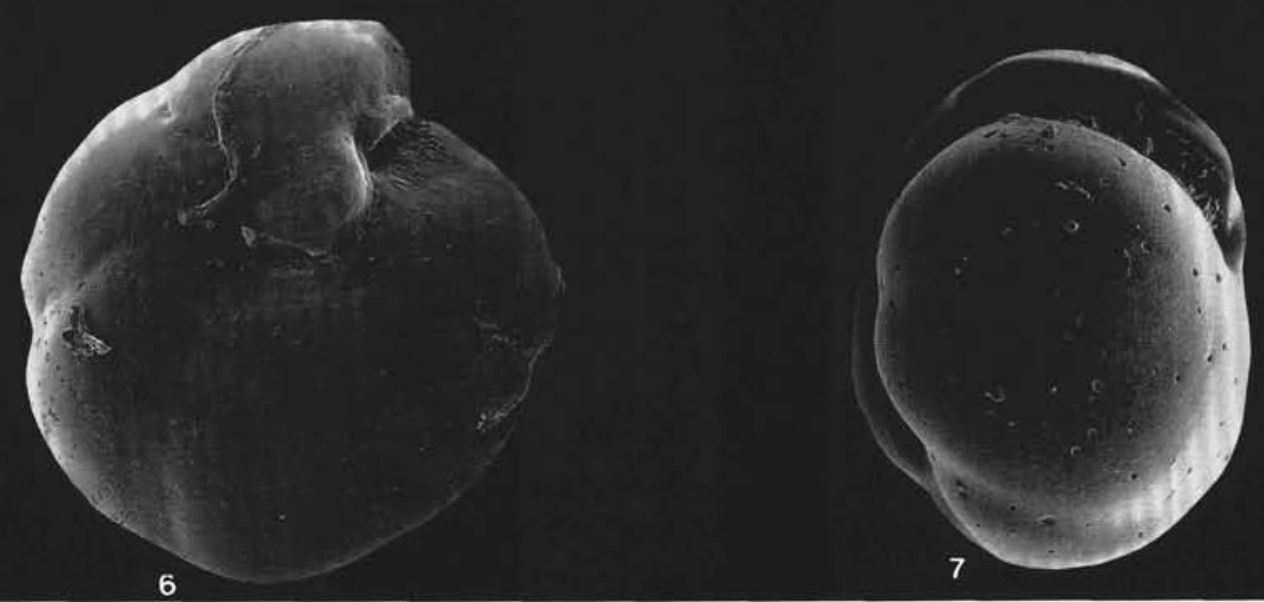

Plate 2. 1. Gyroidinoides altiformis. a. Peripheral view, Sample 110-672A-5H-4, 68-70 cm, $\times 300$. b. Umbilical view, Sample $110-672 \mathrm{~A}-7 \mathrm{H}-1,80-82$ $\mathrm{cm}, \times 150$. 2. Gyroidinoides sp. 2 , Sample $110-672 \mathrm{~A}-5 \mathrm{H}-5,97-99 \mathrm{~cm}, \times 150$. 3. Melonis barleeanus, Sample $110-672 \mathrm{~A}-5 \mathrm{H}-1,80-82 \mathrm{~cm}, \times 150$. 4. Nuttallides umboniferus, Sample $110-672 \mathrm{~A}-6 \mathrm{H}-2,98-100 \mathrm{~cm}, \times 150$. 5. Planulina wuellerstorfi, Sample $110-672 \mathrm{~A}-6 \mathrm{H}-2,98-100 \mathrm{~cm}, \times 150$. 6. Oridorsalis umbonatus, Sample $110-672-\mathrm{A}-6 \mathrm{H}-2,98-100 \mathrm{~cm}, \times 150$. 7. Pullenia osloensis, Sample $110-672 \mathrm{~A}-6 \mathrm{H}-2,98-100 \mathrm{~cm}, \times 300$. 


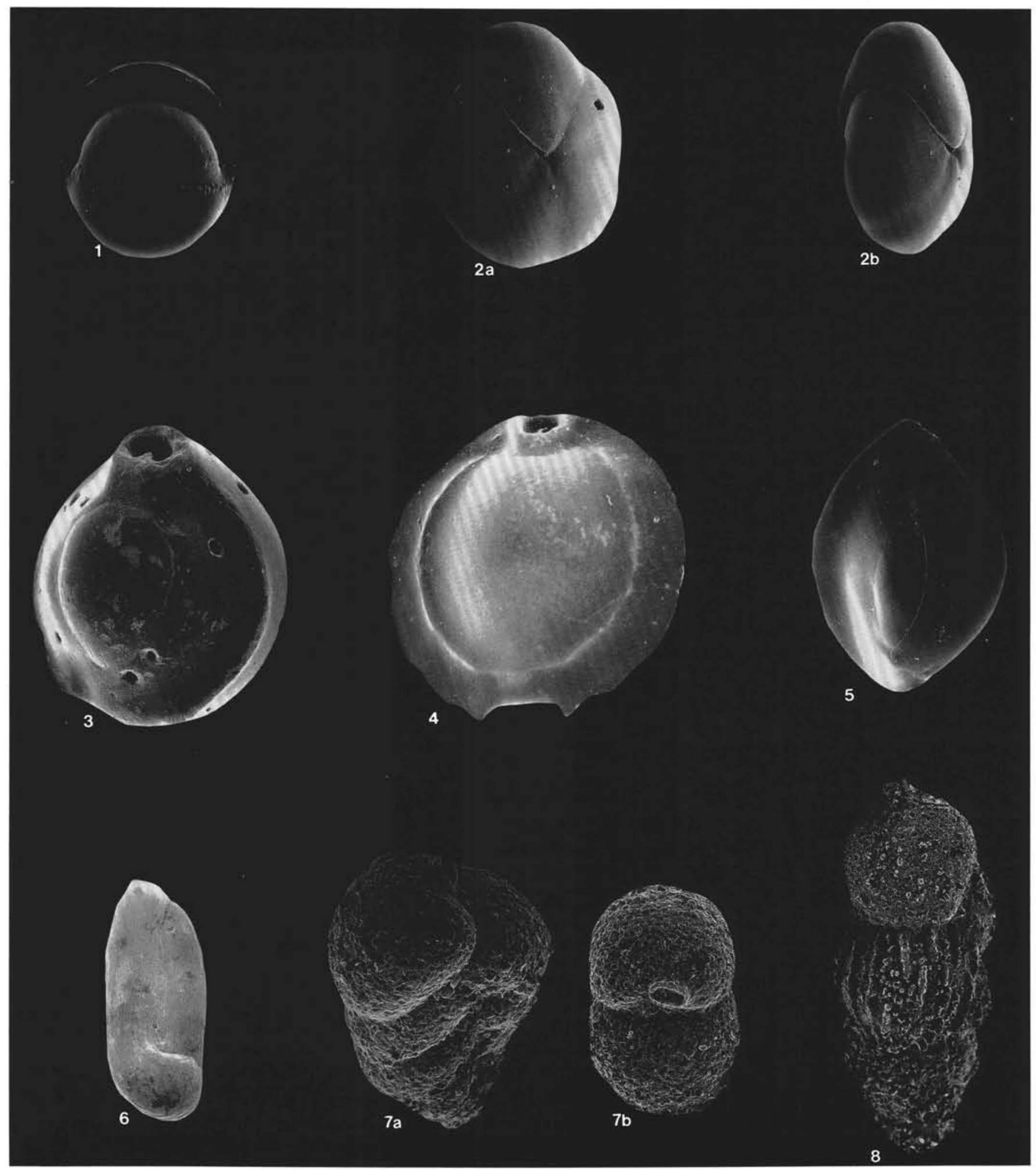

Plate 3. 1. Pullenia bulloides, Sample $110-672 \mathrm{~A}-6 \mathrm{H}-2,98-100 \mathrm{~cm}, \times 150$. 2. Pullenia subcarinata, Sample $110-672 \mathrm{~A}-7 \mathrm{H}-4,80-82 \mathrm{~cm}, \times 150$. 3. Pyrgo sp. 1, Sample 110-672A-4H-3, 79-81 cm, $\times 150$. 4. Pyrgo murrhina, Sample 110-672A-5H-3, 80-82 cm, $\times 120$. 5. Quingueloculina cf. weaveri, Sample 110-672A-4H-5, 79-81 cm, $\times 150$. 6. Quinqueloculina venusta, Sample $110-672 \mathrm{~A}-4 \mathrm{H}-5,79-81 \mathrm{~cm}, \times 150$. 7. Siphotextularia catenata, Sample 110-672A-5H-3, 80-82 cm. a. $\times 300$. b. $\times 300$. 8. Uvigerina hollicki, Sample 110-672A-3H-2, 99-101 cm, $\times 150$. 